\title{
CYP2C9 Substrate
}

National Cancer Institute

\section{Source}

National Cancer Institute. CYP2C9 Substrate. NCI Thesaurus. Code C120266.

Any substance acted upon by cytochrome P450 2C9. 